\title{
Influence of dust and oil accumulation on the effectiveness of photocatalytic concrete surfaces
}

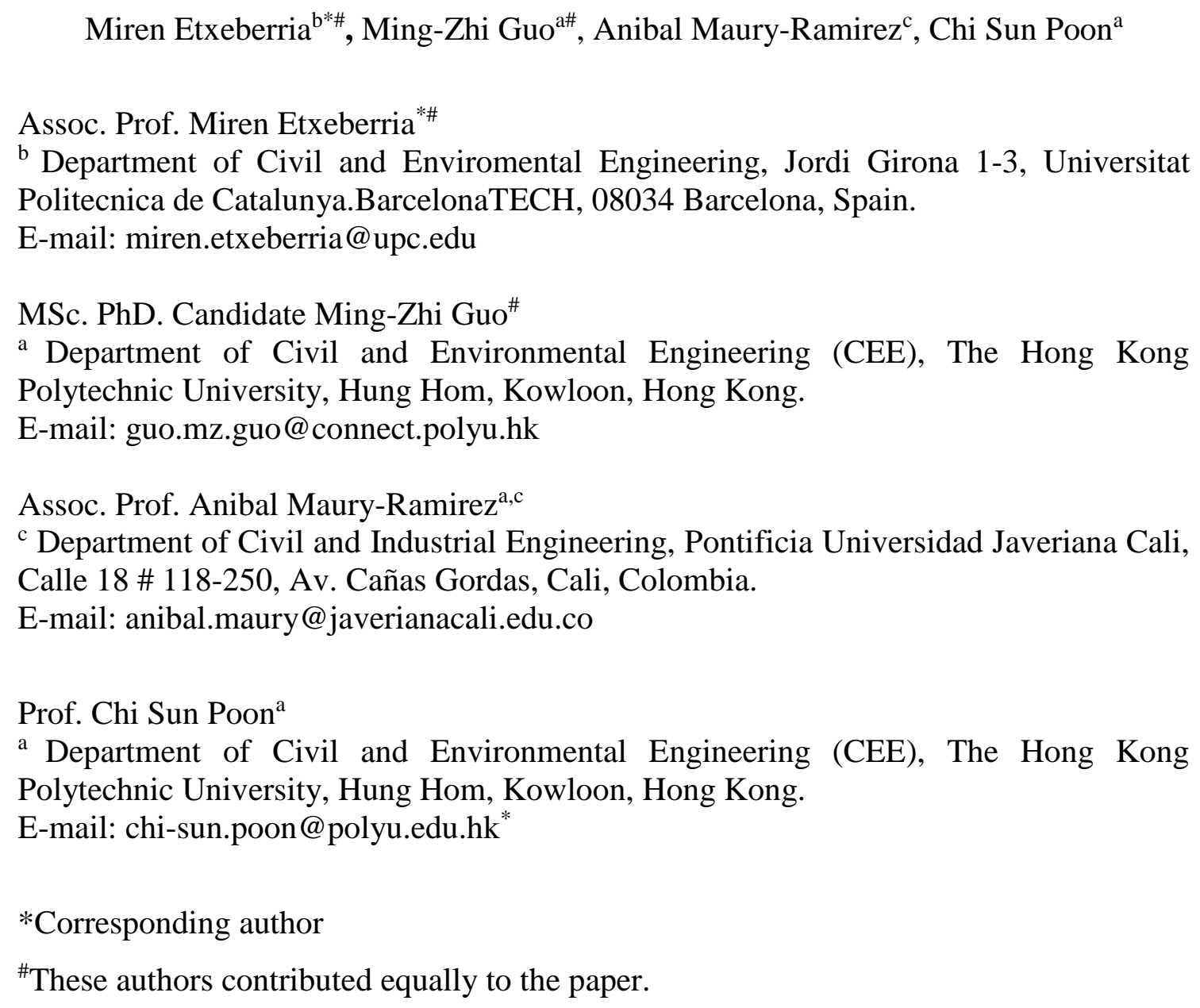

\section{Abstract}

The day to day negative effect of contaminating substances on the $\mathrm{NO}_{\mathrm{x}}$ removal effectiveness of photocatalytic surfaces and their recovery capacity after undergoing cleansing is of real academic and practical interest. This study deals with the analysis of the $\mathrm{NO}_{\mathrm{x}}$ removal effectiveness of two different types of photocatalytic concrete surface layers incorporating nano- $\mathrm{TiO}_{2}$ particles. Both types of surfaces were examined before and after being subjected to dust accumulation and oil impregnation. In addition, the recovery of their $\mathrm{NO}_{\mathrm{x}}$ removal capacity after undergoing various cleansing processes was also evaluated. The results were compared to those of their respective reference samples. The results showed that the high $\mathrm{NO}_{\mathrm{x}}$ removal capacity of the spray coated samples was partially maintained even after a high concentration of dust accumulation. However, the water cleansing process employed was sufficient enough to recover the 
lost $\mathrm{NO}_{\mathrm{x}}$ removal capacity. It was also discovered that the nano- $\mathrm{TiO}_{2}$ particles lost nearly all their photocatalytic capacity after being subjected to oil impregnation, and that the cleansing processes, either by an alkaline detergent or using a n-hexane solvent, failed to recover the initial $\mathrm{NO}_{\mathrm{x}}$ removal capacity.

Keywords: concrete surface; nano- $\mathrm{TiO}_{2}$; photocatalytic, $\mathrm{NO}_{\mathrm{x}}$ removal; dust accumulation; oil impregnation

\section{INTRODUCTION}

The use of photocatalytic building materials to reduce atmospheric pollutants, which have a negative effect on health, particularly amongst children and the elderly, is becoming increasingly more necessary. Vehicle traffic emissions, as well as contaminants caused by housing and industry, are the main sources of atmospheric pollution in dense urban areas. Many organic compounds and air pollutants including nitrogen oxides and sulfur dioxide can be decomposed by ultraviolet (UV) radiation. However, this process is extremely slow. Photocatalytic materials such as nano-titanium dioxide $\left(\mathrm{TiO}_{2}\right)$, in the presence of UV light (sunlight), can accelerate this process through the decomposition of organic and inorganic substances, including air pollutants such as $\mathrm{NO}_{\mathrm{x}}, \mathrm{SO}_{2}$, and VOC's (Hodgson et al., 2007; Hassan, 2009).

Over the last twenty years there have been numerous studies dealing with ways of improving the quality of urban air through the incorporation of nano- $\mathrm{TiO}_{2}$ into concrete block production (Murata et al., 1999; Poon and Cheung, 2007; Chen and Poon, 2009a; Chen and Poon, 2009b; Hüsken et al., 2009; Ballari et al., 2010; Guo and Poon, 2013; Ballari et al., 2011) as well as the manufacture of surface treated stone and rendering materials (Franzoni et al., 2014; Munafo et al. 2015). However, as yet there has been no in depth evaluation of the durability of the nano- $\mathrm{TiO}_{2}$ surface coating. According to Hassan et al. (2010), there was a small decrease in the NO removal efficiency during the wearing down of the samples that had $5 \% \mathrm{TiO}_{2}$ incorporation. Results of the SEM-EDS analysis also confirmed that when compared with the original samples the relative concentration of $\mathrm{Ti}$ on the worn out specimens did not substantially change. However, Guo et al. (2013) found that $\mathrm{TiO}_{2}$-dip-coated mortars almost totally lost the bactericidal ability after being subjected to a harsh weathering process. 
Olabarrieta et al. (2012) presented an analysis of the effect of chemical and physical transformations associated with water flow on two intrinsically different photocatalytic coatings. Their work highlighted the deactivation of the active sites of $\mathrm{TiO}_{2}$ upon prolonged immersion in water, which was found to reduce the performance of the photocatalytic materials. They hypothesized that sodium chloride and UV light somehow modified the $\mathrm{TiO}_{2}-\mathrm{TiO}_{2}$ and $\mathrm{TiO}_{2}$-glass substrate interaction, resulting in facilitating the release of the $\mathrm{TiO}_{2}$ nanoparticles into the surrounding water. According to De Melo et al. (2012), external agents such as dirt and abrasion are determinant in the efficiency loss of the $\mathrm{NO}_{\mathrm{x}}$ removal capacity on the concrete block surfaces. Rainwater or the simple water cleansing (without pressure) of the block surfaces is not sufficient to ensure recovery of the photocatalytic activity, and thus periodic maintenance cleansing of the surface is required by means of employing a water jet.

In this research work, the influence of dust and oil accumulation on the $\mathrm{NO}_{\mathrm{x}}$ removal capacity of the photocatalytic nano- $\mathrm{TiO}_{2}$ based concrete surfaces as well as their recovery to $\mathrm{NO}_{\mathrm{x}}$ removal after cleaning process are presented. Two separate types of photocatalytic concrete surface layers were produced. One set of samples was produced using $\mathrm{TiO}_{2}$ as an addition (in $5 \%$ by cementitious materials weight), whereas, the other set was spray coated with a nano- $\mathrm{TiO}_{2}$ solution. The effectiveness of the $\mathrm{NO}_{\mathrm{x}}$ removal capacity of the two types of samples before and after being subjected to dust accumulation and oil impregnation was determined. The recovery of their respective $\mathrm{NO}_{\mathrm{x}}$ removal capacity after treatment by a myriad of cleansing processes was subsequently evaluated.

\section{MATERIALS AND SAMPLE PREPARATION}

\subsection{Materials}

A commercially available nano- $\mathrm{TiO}_{2}$ powder (P25, Degussa) was used as the photocatalyst in all the experiments. The particle size of the $\mathrm{TiO}_{2}$ was $20-50 \mathrm{~nm}$, with a specific BET surface area of $50 \pm 15 \mathrm{~m}^{2} \cdot \mathrm{g}^{-1}$. ASTM Type I Ordinary Portland cement (OPC, Green Island Cement Limited, Hong Kong) and fly ash (FA) were used as the cementitious materials. FA was added as a pozzolana to control the alkali-silica reaction (ASR) between the silica-rich glass cullet (used as aggregate in preparing the photocatalytic cement mortar) and the alkali in the cement. Their physical and chemical properties are listed in Table 1 . The nano- $\mathrm{TiO}_{2}$-based concrete surface layers were prepared by employing fine aggregates obtained from crushed recycled glass (RG) 
cullet derived from post-consumer beverage glass bottles. The post-consumer beverage glass used was sourced from a local Hong Kong based eco-construction material company. Prior to their experimental use, all the discarded glass bottles were washed and then crushed by a mechanical crusher before being finally sieved to obtain the desired particle size. The particle size distribution of the RG used in the experiment is shown in Table 2.

\subsection{Mix proportions and production process}

The mix proportion (by weight) for the two types of concrete surface layers was 0.75:0.25:3.0:0.3 (OPC: FA: RG: water).

The procedures for the preparation of the concrete surface layers were as follows. First, all the proportioned materials were mixed uniformly for approximately 5 minutes using a mechanical mixer (nano- $\mathrm{TiO}_{2}$ particles were added in the Intermixed-type 1 mixture). Then, the steel moulds (an internal dimension of $200 \times 100 \times 5 \mathrm{~mm}$ ) were filled to maximum capacity (about $250 \mathrm{~g}$ ) and the resulting mixture was then hand compacted before undergoing two further mechanical compacting stages of $500 \mathrm{kN}$ and $600 \mathrm{kN}$ at a rate of $500 \mathrm{kN} \cdot \mathrm{min}^{-1}$

The $\mathrm{TiO}_{2}$ sprayed coated samples (SP-Type 2) were produced via the use of a suspension of methanol and P25 $\left(30 \mathrm{~g} \cdot \mathrm{L}^{-1}\right)$ which was sprayed on to the mortar surface. A detailed explanation of the procedure employed is as follows. The mortar mixtures (without $\mathrm{TiO}_{2}$ ) were first placed in the prepared steel moulds where they were hand compacted before being spray coated 10 times with the $\mathrm{TiO}_{2}$-solution. The mixture was then subjected to mechanical compacting similar to that previously mentioned, before undergoing a further 10 spray coatings. All spray coating was carried out within the first 20 minutes after the surface layer material was introduced into the moulds.

The prepared surface layers were removed 24 hours later from their moulds and then tightly wrapped in plastic film during curing until further testing.

\subsection{Properties of concrete surface layers}

The physical and mechanical properties of the two types of concrete surface layers produced (intermixed-Type 1 and SP-Type 2) were determined using cubic test specimens of $70 \times 70 \times 70 \mathrm{~mm}$ according to ASTM C642-06. The specimens were produced by compacting the concrete specimens in three layers. The first two layers were compacted manually using a wooden rod. The third layer was compacted 
mechanically via a press in the same manner as described in Section 2.2. Table 3 shows the properties of intermixed-Type 1 and SP-Type 2 samples. It is well-known that the use of nano- $\mathrm{TiO}_{2}$ particles can have an impact on reducing the fluidity of the intermixed-Type 1 mixture and consequently reducing also the homogeneity of the prepared samples, thus leading to slightly reduced compressive strengths, a fact also detected by other researchers (Lucas et al., 2013; Jimenez-Relinque et al., 2015).

\section{METHODOLOGY}

\subsection{Photocatalytic conversion of $\mathrm{NO}_{\mathrm{x}}$}

The photocalytic conversion of $\mathrm{NO}_{\mathrm{x}}$ was tested through the use of a continuous flow reactor which was constructed in the laboratory in accordance with JIS R1701-1 specifications. The reactor (length: $300 \mathrm{~mm}$, width: $150 \mathrm{~mm}$ and height: $100 \mathrm{~mm}$ ) was completely sealed and free of all leakage. The test samples were placed on a rack in the centre of the reactor. A schematic diagram of the experimental setup is shown in Figure 1. Detailed information on the reactor and the required equipment employed to carry out the photocatalytic $\mathrm{NO}_{\mathrm{x}}$ conversion test can be found in our previous studies (Guo et al., 2015). The entire experiment was carried out at the ambient temperature of $25 \pm 3{ }^{\circ} \mathrm{C}$. The flow of the testing gas (1000 ppb NO) was adjusted by two flow controllers at a rate of $3 \mathrm{~L} \cdot \mathrm{min}^{-1}$ and the relative humidity $(\mathrm{RH})$ was controlled at $30 \pm 5 \%$. The UV intensity at the centre of the reactor was $2 \mathrm{~W} \cdot \mathrm{m}^{-2}$. All photocatalytic conversion processes were carried out by first introducing the testing gas stream into the reactor in the absence of UV radiation for a minimum of half an hour. The reason for this was to ensure that both the desired RH and the gas-solid adsorption-desorption equilibrium was reached, after which the UV lamps were turned on for the photocatalytic process to begin. The NO removal test took 1 hour per sample, during this time period the concentration changes of $\mathrm{NO}$ and $\mathrm{NO}_{2}$ at the outlet were recorded. Every sample was tested three times and the average value together with the standard deviation was noted. The details of the calculation of the amount of $\mathrm{NO}_{\mathrm{x}}$ removal have been described previously (Guo et al., 2015) and are expressed as a subtraction of the $\mathrm{NO}_{2}$ generated from the NO removed. The calculation of the amount of $\mathrm{NO}_{\mathrm{x}}$ removal, following the instructions detailed in JIS R 1701-1, is shown below: 
175

where $Q_{N O x}\left(\mu \mathrm{mol} \cdot \mathrm{m}^{-2} \cdot \mathrm{h}^{-1}\right)$ is the amount of nitric oxides removed by the test sample, $[\mathrm{NO}]_{0}$ and $\left[\mathrm{NO}_{2}\right]_{0}(\mathrm{ppm})$ are the inlet concentration of nitrogen monoxide and nitrogen dioxide, respectively, $[\mathrm{NO}]$ and $\left[\mathrm{NO}_{2}\right](\mathrm{ppm})$ are the outlet concentration of nitrogen monoxide and nitrogen dioxide, respectively, $t(\mathrm{~min})$ is the time of removal operation, $f$ $\left(\mathrm{L} \cdot \mathrm{min}^{-1}\right)$ is the flow rate converted into that at the standard state $\left(0^{\circ} \mathrm{C}, 1.013 \mathrm{kPa}\right), A$ $\left(\mathrm{m}^{2}\right)$ is the surface area of cement paste samples, $T(1 \mathrm{~h}$ for all experiments $)$ is the duration of the photocatalytic process, and 22.4 represents the volume of 1 mole ideal gas at the standard state, which is $22.4 \mathrm{~L}$ (ideal gas law).

\subsection{Worsening and recovery of photocatalytic activities}

The effectiveness of the $\mathrm{NO}_{\mathrm{x}}$ removal capacity of the intermixed-Type 1 and SP-Type 2 samples after the surfaces were subjected to dust accumulation and oil impregnation was determined. After which, the samples were subjected to several cleansing processes, and the recovery of their $\mathrm{NO}_{\mathrm{x}}$ removal capacity was then evaluated.

\subsubsection{Dust accumulation process and its assessment}

\section{Dust characterization}

A fine dust (ISO 12103-1 A2) provided by Powder Technology Inc. was employed in order to simulate the effect of natural dust. Table 4 describes the grading size distribution of those dust particles (the data was provided by Powder Technology Inc.). The specific weight of the dust was $2.65 \mathrm{~g} \cdot \mathrm{cm}^{-3}$, and $\mathrm{SiO}_{2}$ and $\mathrm{Al}_{2} \mathrm{O}_{3}$ were the main chemical components. The compositions of the dust (by weight) are given in Table 5.

\section{Dust accumulation and cleansing process}

The photocatalytic effectiveness of concrete surface layers could be affected by dust accumulation on their surface. Although it is not easy to simulate the real situation during application in the laboratory, in this work a chamber designed and constructed for that purpose was used. The test chamber $(1 \times 0.6 \times 0.6 \mathrm{~m})$ was made with ESD acrylic plates which were both transparent and antistatic. The test dust was injected by the dust generator (RBG 1000, PALAS) into the test chamber and mixed with air via means of a 
fan. Dust was deposited slowly and naturally on the surface of the samples, which were positioned in the centre of the chamber (Figure 2).

The amounts of dust accumulated on both the surfaces of the intermixed-Type 1 and SP-Type 2 samples were 0, 10, 18 and $37 \mathrm{gr} \cdot \mathrm{m}^{-2}$. Figure 3a shows several samples subjected to the dust accumulation process. Figure $3 \mathrm{~b}$ shows, the samples (1) and (2) with 10 and $37 \mathrm{gr} \cdot \mathrm{m}^{-2}$ of dust accumulation on the surface, respectively. The $\mathrm{NO}_{\mathrm{x}}$ removal capacity of the intermixed-Type 1 and SP-Type 2 samples with different weight of dust accumulation on their surfaces was immediately evaluated. Then, the cleansing processes were carried out in order to evaluate the recovery of the $\mathrm{NO}_{\mathrm{x}}$ removal ability of the samples. Two cleansing processes were applied on each sample. First, slow flowing tap water, with an approximately flow rate of $6.25 \mathrm{~cm}^{3} / \mathrm{s}$, was applied to the surface of the samples. Second, besides the water cleansing (under the same conditions), an electric brush was also employed to clean the samples' surfaces. Immediately after the cleansing process, all the samples were oven-dried $\left(60{ }^{\circ} \mathrm{C}\right.$ for $24 \mathrm{~h}$ ) until $\mathrm{NO}_{\mathrm{x}}$ removal testing. The photocatalytic activity of each sample was evaluated and the obtained results were compared to those of the reference samples (without dust accumulation).

\subsubsection{Oil accumulation process and its assessment} Oil accumulation and cleansing process

A synthetic motor oil of $15 \mathrm{~W}-40$ viscosity was employed to impregnate the surfaces of the intermixed-Type 1 and SP-Type 2 samples. The surfaces of the concrete layers were impregnated by separately using two types of oil-solvent mixtures. Firstly, a low viscosity oil-solvent mixture consisting of $50 \%$ weight of oil and $50 \%$ weight of ethanol (with ratio of 1:1) was prepared. This low viscosity mixture was then applied on the samples in a dose of $200 \mathrm{~g}$ per $\mathrm{m}^{2}$ of concrete surface. Secondly, $400 \mathrm{~g}$ of undiluted motor oil per $\mathrm{m}^{2}$ of concrete surface was also used to contaminate the surface of the samples. A $3 \mathrm{~mL}$ pipette dropper was employed, the oil-solvents being distributed drop by drop in order to guarantee their homogeneous accumulation on the surface. 5 pipettes were employed to disperse all the oil-solvents on each concrete sample over a fixed area of $20 \times 10 \mathrm{~cm}^{2}$. The capacity of degradation of $\mathrm{NO}_{\mathrm{x}}$ via the intermixed-Type 1 and SPType 2 samples after oil accumulation was determined. Several cleansing processes were used in order to remove the oil from the samples. The oil contaminated samples were separately cleaned by adding two oil removing products to the surfaces; an 
alkaline industrial detergent and an organic solvent (n-hexane). The spray SP-Type 2 samples were cleaned by means of adding the n-hexane solvent to the surface as well as submerging the samples in hexane for another 12 hours (named as cleaned-hexane-2).

\section{RESULTS}

\subsection{Photocatalytic $\mathrm{NO}_{\mathrm{x}}$ removal of intermixed-Type 1 and spray SP-Type 2 samples}

Figure 4 illustrates the $\mathrm{NO}_{\mathrm{x}}$ concentration profiles when the reference intermixed-Type 1 and SP-Type 2 samples after undergoing the photocatalytic $\mathrm{NO}_{\mathrm{x}}$ removal test. The SPType 2 samples showed a greater reduction of $\mathrm{NO}_{\mathrm{x}}$ capacity. This finding proved to be consistent with our previous work (Guo et al., n.d. ). The elimination rate of $\mathrm{NO}_{\mathrm{x}}$ by the intermixed-Type 1 and SP-Type 2 samples were $136.5 \mu \mathrm{mol} \cdot \mathrm{h}^{-1} \cdot \mathrm{m}^{-2}$ and $255.0 \mu \mathrm{mol} \cdot \mathrm{h}^{-}$ ${ }^{1} \cdot \mathrm{m}^{-2}$, respectively. Thus, the SP-Type 2 sample proved to be $80 \%$ more effective than the intermixed-Type 1 samples. This far superior $\mathrm{NO}_{\mathrm{x}}$ photocatalytic removal performance of the SP-Type 2 samples can be attributed to a much higher amount of $\mathrm{TiO}_{2}$ particles on the sample's surface (supported by the following SEM-EDX analysis). As a result, most of the $\mathrm{TiO}_{2}$ surface particles were able to gain easy access to the UV light irradiation. In contrast, a high percentage of nano- $\mathrm{TiO}_{2}$ surface particles of the intermixed-Type 1 samples were completely enveloped by the hydration products, and hence were not in direct contact with the UV-light, as was previously described (Guo et al., 2013).

SEM and EDX were employed to analyse the two types of samples. Figure $5 \mathrm{a}$ and $5 \mathrm{~b}$ clearly illustrate the morphological differences of the intermixed-Type1 and SP-Type2 samples studied, respectively. And the EDX analysis revealed that the percentage of titanium element presented on the surface of intermixed-Type 1 and SP-type 2 samples was $3.3 \%$ and $26.4 \%$, respectively. Figure $5 \mathrm{a}$ and $5 \mathrm{~b}$ also illustrate that some nano- $\mathrm{TiO}_{2}$ particles in the intermixed-Type 1 samples were completely enveloped by the surrounding cement hydrated products, which more than likely impaired the $\mathrm{NO}_{\mathrm{x}}$ removal capacity. Whereas, most of the spray-coated $\mathrm{TiO}_{2}$ particles were free from the accumulation of the hydration products, and thus could be fully exposed to UV light. Therefore, the SEM-EDX results are well validated by the aforementioned explanations with respect to the observed differences in the photocatalytic $\mathrm{NO}_{\mathrm{x}}$ removal. 

cleansing processes

\subsubsection{Influence of dust accumulation}

Figure 6 shows the $\mathrm{NO}_{\mathrm{x}}$ removal profiles of the intermixed-Type 1 and SP-Type 2 samples after being subjected to different amounts of dust accumulation on the surface. In general, the samples with a higher volume of accumulated dust displayed less ability to remove $\mathrm{NO}_{\mathrm{x}}$, regardless of the sample types. For example, the $37 \mathrm{~g} \cdot \mathrm{m}^{-2}$ of dust accumulation significantly reduced the $\mathrm{NO}_{\mathrm{x}}$ removal ability of both types of samples tested (from 136.5 to $39.5 \mu \mathrm{mol} \cdot \mathrm{h}^{-1} \cdot \mathrm{m}^{-2}$ for intermixed-Type 1 and from 254.9 to 148.7 $\mu \mathrm{mol} \cdot \mathrm{h}^{-1} \cdot \mathrm{m}^{-2}$ for SP-Type 2 samples, respectively). However, it must be pointed out that even after $37 \mathrm{~g} \cdot \mathrm{m}^{-2}$ of dust accumulation, the SP-Type 2 samples were still able to deliver a high photocatalytic $\mathrm{NO}_{\mathrm{x}}$ removal ability. This can be explained by the fact that the dust accumulated on the surface was not densely compacted (no external force was applied to the dust covered surface), thus the light blocking effect was not so significant. Moreover, taking into consideration that the size of nano- $\mathrm{TiO}_{2}$ particles used in this study was far smaller than that of the dust particles (see Table 4), the UV light was still able to penetrate through those dust particles to reach the $\mathrm{TiO}_{2}$ particles underneath, some of which were still able to produce the photocatalytic activity. More interestingly, it was clearly observed that the dust accumulation noted had less influence on the SP-Type 2 samples than on those of the intermixed-Type 1 samples. This fact was consistent with the previous $\mathrm{NO}_{\mathrm{x}}$ removal results of the reference samples (section 4.1). For example (see Figure 6), the SP-Type 2 samples still retained a relatively higher capacity of $\mathrm{NO}_{\mathrm{x}}$ removal after exposure to $37 \mathrm{~g} \cdot \mathrm{m}^{-2}$ of dust accumulation, (above $145 \mu \mathrm{mol} \cdot \mathrm{h}^{-1} \cdot \mathrm{m}^{-2}$ ), which proved to be even higher than that of the intermixed-Type 1 samples without any dust accumulation $\left(136.5 \mu \mathrm{mol} \cdot \mathrm{h}^{-1} \cdot \mathrm{m}^{-2}\right)$.

\subsubsection{Rejuvenation of $\mathrm{NO}_{\mathrm{x}}$ removal by the cleansing processes}

Figure 7 shows the surface appearance of the samples after they were subjected to different cleansing processes. The surfaces of all the intermixed-Type 1 samples were similar in appearance to those of the reference sample after the application of the two different cleansing processes. However, for the SP-Type 2 samples, the intensity of the white colour on the surface (an indication of the $\mathrm{TiO}_{2}$ amount) was slightly decreased after the cleansing process due to the washing away of some nano- $\mathrm{TiO}_{2}$ particles from the surface. 
Figures $8 \mathrm{a}$ and $8 \mathrm{~b}$ demonstrate the removal capacity of $\mathrm{NO}_{\mathrm{x}}$ on the two types of samples after being subjected to the two cleansing processes. It was observed that both the intermixed-Type 1 and SP-Type 2 samples recovered their initial $\mathrm{NO}_{\mathrm{x}}$ removal capacity. According to the test results of the intermixed-Type 1 samples, a comparative study of the additional use of brush cleaning (Fig. 8b) with that of samples only cleaned with water (Fig. 8a) showed that there was no further improvement in the capacity of $\mathrm{NO}_{\mathrm{x}}$ removal. This indicates that just washing with water is sufficient enough to recover their initial photocatalytic $\mathrm{NO}_{\mathrm{x}}$ removal ability. Unexpectedly, the process of cleansing improved the $\mathrm{NO}_{\mathrm{x}}$ removal capacity of the intermixed-Type 1 reference sample. The samples subjected to a higher dust accumulation achieved a higher $\mathrm{NO}_{\mathrm{x}}$ removal capacity. The reason for this could be the abrasion action of the cleansing process, which led to more nano- $\mathrm{TiO}_{2}$ particles (previously embedded) being exposed to the air, thus facilitating an increase in the available active $\mathrm{TiO}_{2}$ sites on the surface (JimenezRelinque et al., 2015). The cleansing process resulted in an increased surface roughness and exposure of active surface particles, resulting in a slight increase in the $\mathrm{NO}_{\mathrm{x}}$ removal capacity (De Melo et al., 2012; Sugrañez et al., 2013; Jimenez-Relinque et al., 2015).

A comparison study of the reference samples with that of the SP-Type 2 samples showed that the brush cleansing (Fig 8b) slightly reduced the $\mathrm{NO}_{\mathrm{x}}$ removal capacity. The use of brush cleansing caused the removal of a certain amount of nano- $\mathrm{TiO}_{2}$ particles from the surface of the samples, thus contributing to a decrease in their $\mathrm{NO}_{\mathrm{x}}$ removal capacity.

4.3 Influence of motor oil accumulation on $\mathrm{NO}_{\mathrm{x}}$ removal capacity and recovery via cleansing process

\subsubsection{Influence of motor oil accumulation}

Figure 9a illustrates the $\mathrm{NO}_{\mathrm{x}}$ removal activity of intermixed-Type 1 samples and their corresponding reference samples after being impregnated with different concentrations of oil. Motor oil concentrations of $200 \mathrm{~g} \cdot \mathrm{m}^{-2}$ and $400 \mathrm{~g} \cdot \mathrm{m}^{-2}$ on the sample surfaces resulted in a complete loss of the $\mathrm{NO}_{\mathrm{x}}$ removal capacity of the intermixed-Type 1 sample. Similarly, (Fig 9b) shows that the SP-Type 2 samples suffered a loss of $80-90 \%$ in their $\mathrm{NO}_{\mathrm{x}}$ removal capacity. It was also observed that when $10 \%$ of the surface of both the intermixed-Type 1 and SP-Type 2 specimens were impregnated with oil, approximately $10 \%$ of the original 
$341 \mathrm{NO}_{\mathrm{x}}$ removal efficiency was lost. Apparently, the presence of oil on the surface of the nano- $\mathrm{TiO}_{2}$ particles completely isolated them from contacting with air and light, and the effect of the localized contamination did not spread out to other parts of the concrete surface.

\subsection{2 $\mathrm{NO}_{\mathrm{x}}$ removal recovery by different cleansing processes}

Figures $10 \mathrm{a}$ and $10 \mathrm{~b}$ illustrate the $\mathrm{NO}_{\mathrm{x}}$ removal capacity when the samples were impregnated with the motor oil and after undergoing different cleansing processes. Both cleansing methods were found to be inefficient in removing the motor oil. For example, the SP-Type 2 sample did not fully recover its $\mathrm{NO}_{\mathrm{x}}$ removal capacity after being cleaned or treated with the n-hexane solution.

As mentioned in section 4.3.1, the samples which had $10 \%$ of their surface impregnated with motor oil lost approximately $10 \%$ of their $\mathrm{NO}_{\mathrm{x}}$ removal capacity. However, applying the cleansing agents extended the spread of the oil to cover the entire sample surface. Consequently, the samples having $10 \%$ of their area impregnated with motor oil experienced a decrease of $\mathrm{NO}_{\mathrm{x}}$ removal capacity from 219.8 to $188.9 \mu \mathrm{mol} \cdot \mathrm{h}^{-1} \cdot \mathrm{m}^{-2}$ when the samples were cleaned by the n-hexane solution. This demonstrates the very serious detrimental effect of oil contamination on the photocatalytic activities of the concerned samples.

A SEM-EDX analysis was undertaken to examine the surface morphology of the samples in order to identify changes of the nano- $\mathrm{TiO}_{2}$ particles before (Figure 11a) and after (Figure 11b) applying the oil contamination. The morphology of the nano- $\mathrm{TiO}_{2}$ particles presented on the surface of the contaminated samples was quite similar to those of the reference sample. However, an EDX analysis revealed that the titanium content was much lower. This in all probability was due to the presence of the oil envelope surrounding the surface of $\mathrm{TiO}_{2}$ particles. Being oleophobic, the $\mathrm{TiO}_{2}$ nanoparticles could have tried to stay apart from the oil and thus pushed themselves toward the bottom (i.e. toward the sliding surface), where they deposited themselves on the bottom surface due to gravity (Ingole et al., 2013).

Probably, the most effective method for cleaning the oil contaminated samples would be to leave them for a sustained period of time under UV light, as the photocatalysis of the nano- $\mathrm{TiO}_{2}$ particles can decompose the adsorbed organic molecules due to a lightinduced self-cleansing and antifouling function (Li et al., 2015). Longer term studies are required to ascertain such effects. 


\section{CONCLUSIONS}

377

The following conclusions can be made based on the results of this study:

- According to the original samples:

- The concrete surface layers spray-coated with nano- $\mathrm{TiO}_{2}$ particle solution were more effective in $\mathrm{NO}_{\mathrm{x}}$ removal than the concrete surfaces produced using $5 \%$ nano- $\mathrm{TiO}_{2}$ as intermixed additive. The main reason for this was that the major part of the spray-coated $\mathrm{TiO}_{2}$ particles had a higher accessibility to UV light irradiation.

- According to dust accumulation and the corresponding cleansing process:

- A high amount of dust accumulation on the $5 \% \mathrm{TiO}_{2}$ intermixed concrete surface layers severely impaired their $\mathrm{NO}_{\mathrm{x}}$ removal capacity. However, the spray coated samples were able to partially maintain their initial $\mathrm{NO}_{\mathrm{x}}$ removal capacity.

- The water cleansing process was sufficient to recover the initial $\mathrm{NO}_{\mathrm{x}}$ removal capacity of both types of samples. The spray coated samples lost a small quantity of nano- $\mathrm{TiO}_{2}$ particles upon being subjected to water and brush cleansing, resulting in a slight decrease in the $\mathrm{NO}_{\mathrm{x}}$ removal capacity.

- According to the effect of oil impregnation and the corresponding cleansing process:

- Oleophobic and high specific surface nano- $\mathrm{TiO}_{2}$ particles were confined below the oil, thus losing their photocatalytic capacity. The samples produced by employing nano- $\mathrm{TiO}_{2}$ as additive resulted in a complete loss of $\mathrm{NO}_{\mathrm{x}}$ removal capacity. While the samples coated by spraying nano$\mathrm{TiO}_{2}$ solution suffered a loss of $80-90 \%$ reduction of their initial $\mathrm{NO}_{\mathrm{x}}$ removal capacity.

o The cleansing processes, either with an alkaline detergent or with a nhexane solvent were not effective in recovering their respective $\mathrm{NO}_{\mathrm{x}}$ removal capacity.

Overall, the spray coated samples were much more effective in $\mathrm{NO}_{\mathrm{x}}$ removal than the intermixed samples in any mode of the sample tested (reference, contaminated or cleansed samples). 


\section{Acknowledgement}

The authors wish to thank the Hong Kong Polytechnic University for funding support. M. Etxeberria also wishes to thank the Ministry of Education, Culture and Sport, Spain, for the "Jose Castillejo" young researcher programme (CAS12/00167) which provided the financial support.

\section{References}

Ballari, M.M., Hunger, M., Hüsken, G.B.H., 2010. NOx photocatalytic degradation employing concrete pavement containing titanium dioxide. Appl. Catal. B. 95, $245-254$.

Ballari, M. M., Yu, Q.L., Brouwers, H.J.H., 2011. Experimental study of the NO and $\mathrm{NO}_{2}$ degradation by photocatalytically active concrete. Catal. Today. 161 (1), 175180.

Chen, J., Poon, C.S., 2009a. Photocatalytic activity of titanium dioxide modified concrete materials-Influence of utilizing recycled glass cullets as aggregates. J. Environ. Manag. 90, 3436-3442.

Chen, J., Poon, C.S., 2009b. Photocatalytic construction and building materials: from fundamentals to application. Build. Environ. 44, 1899-1906.

De Melo, J.V.S., Trichês, G., Gleize, P.J.P., Villena, J., 2012. Development and evaluation of the efficiency of photocatalytic pavement blocks in the laboratory and after one year in the field. Constr. Build. Mater. 37, 310-319.

Franzoni, E., Fregni, A., Gabrielli, R., Graziani, G., Sassoni, E., 2014. Compatibility of photocatalytic $\mathrm{TiO}_{2}$-based finishing for renders in architectural restoration: A preliminary study. Build. Environ. 80, 125-135.

Guo, M.Z., Ling, T.C., Poon, C.S., 2013. Nano-TiO 2 -based architectural mortar for NO removal and bacteria inactivation: Influence of coating and weathering conditions. Cem. Concr. Comp. 36, 101-108

Guo, M.Z., Ling, T.C., Poon, C.S., (n.d.). Photocatalytic $\mathrm{NO}_{\mathrm{x}}$ degradation of concrete surface layers intermixed and spray-coated with nano- $\mathrm{TiO}_{2}$ : Influence of experimental factors. Submitted to Cem Concr Comp.

Guo, M.Z., Maury-Ramirez, A., Poon, C.S., 2015. Photocatalytic activities of titanium dioxide incorporated architectural mortars: Effects of weathering and activation light. Build. Environ. 94, 395-402.

Guo, M.Z., Poon, C.S., 2013. Photocatalytic NO removal of concrete surface layers 
intermixed with $\mathrm{TiO}_{2}$. Build. Environ. 70, 102-109.

Hassan, M.M., Dylla, H., Mohammad, L.N., Rupnow, T., 2010. Evaluation of the durability of titanium dioxide photocatalyst coating for concrete pavement. Constr. Build. Mater. 24 (8), 1456-1461.

Hassan, M.M., 2009. Evaluation of the environmental impacts of ultrafine/nano photocatalyst coatings for pavements using life-cycle assessment. Paper No. 091057. In: 88th Transportation Research Board Annual Meeting.

Hodgson, A., Destaillat, T.H., Sullivan, D.P., Fisk, W.J., 2007. Performance of ultraviolet photocatalytic oxidation for indoor air cleaning applications. Indoor. Air. $17,305-316$.

Hüsken, G., Hunger, M.B.H., 2009. Experimental study of photocatalytic concrete products for air purification. Build. Environ. 44, 2463-2474.

Ingole, S., Charanpahari, A., Kakade, A., Umare, S.S., Bhatt, D.V., Menghani, J., 2013. Tribological behavior of nano $\mathrm{TiO}_{2}$ as an additive in base oil. Wear. 301 (1-2), $776-785$.

Jimenez-Relinque, E., Rodriguez-Garcia, J.R., Castillo, A., Castellote, M., 2015. Characteristics and efficiency of photocatalytic cementitious materials: Type of binder, roughness and microstructure. Cem. Concr. Res. 71, 124-131.

Li, L., Liu, Z., Zhang, Q., Meng, C., Zhang, T., Zhai, J., 2015. Underwater superoleophobic porous membrane based on hierarchical $\mathrm{TiO}_{2}$ nanotubes: multifunctional integration of oil-water separation, flow-through photocatalysis and self-cleaning. J. Mater. Chem. A. 3, 1279-1286.

Lucas, S.S., Ferreira, V.M., De Aguiar, J.L.B., 2013. Incorporation of titanium dioxide nanoparticles in mortars - Influence of microstructure in the hardened state properties and photocatalytic activity. Cem. Concr. Res. 43 (1), 112-120.

Munafano, P., Goffredo, G.B., Quagliarini, E., 2015. TiO2-based nanocoatings for preserving architectural stone surfaces: An overview. Constr. Build. Mater. 84, 201-218.

Murata, Y., Obata, H., Tawara, H., Murata, K., 1999. NO$_{x}$-cleaning Paving block. Patent NO. 5861205.

Olabarrieta, J., Zorita, S., Peña, I., Rioja, N., Monzón, O., Benguria, P., Scifo, L., 2012. Aging of photocatalytic coatings under a water flow: Long run performance and $\mathrm{TiO}_{2}$ nanoparticles release. Appl. Catal. B. 123-124, 182-192.

Poon, C. S., Cheung, E., 2007. NO removal efficiency of photocatalytic paving blocks 
prepared with recycled materials. Constr. Build. Mater. 21 (8), 1746-1753.

478 Staub de Melo, J.V., Trichês, G., Gleize, P.J.P., Villena, J., 2012. Development and evaluation of the efficiency of photocatalytic pavement blocks in the laboratory and after one year in the field. Constr. Build. Mater. 37, 310-319

481 Sugrañez, R., Álvarez, J.I., Cruz-Yusta, M., Mármol, I., Morales, J., Vila, J., Sánchez, L., 2013. Enhanced photocatalytic degradation of $\mathrm{NO}_{\mathrm{x}}$ gases by regulating the microstructure of mortar cement modified with titanium dioxide. Build. Environ. 69, 55-63.

485

486

487 


\section{LIST OF TABLES}

Table 1. Chemical compositions and physical properties of OPC and FA

Table 2. Particle size distributions of recycled glass cullet

Table 3. Properties of intermixed-Type 1 and SP-Type 2 concrete surface layers after 28 days curing

Table 4. Volume dust Particle distribution

Table 5. Chemical compositions of dust

Table 1. Chemical compositions and physical properties of OPC and FA

\begin{tabular}{|c|c|c|}
\hline & OPC & FA \\
\hline \multicolumn{3}{|l|}{ Chemical composition } \\
\hline $\mathrm{SiO}_{2}$ & 22.18 & 48.14 \\
\hline $\mathrm{Al}_{2} \mathrm{O}_{3}$ & 5.95 & 17.81 \\
\hline $\mathrm{Fe}_{2} \mathrm{O}_{3}$ & 3.37 & 11.63 \\
\hline $\mathrm{CaO}$ & 62.46 & 12.66 \\
\hline $\mathrm{MgO}$ & 1.56 & 4.59 \\
\hline $\mathrm{K}_{2} \mathrm{O}$ & 0.48 & 1.26 \\
\hline $\mathrm{Na}_{2} \mathrm{O}$ & 0.24 & - \\
\hline $\mathrm{TiO}_{2}$ & 0.37 & 0.98 \\
\hline Sulphur content as $\mathrm{SO}_{3}$ & 2.25 & 2.64 \\
\hline Loss in ignition & 0.64 & 3.90 \\
\hline \multicolumn{3}{|l|}{ Physical properties } \\
\hline Specific surface $\left(\mathrm{cm}^{2} \mathrm{~g}^{-1}\right)$ & 3660 & 3960 \\
\hline
\end{tabular}

Table 2. Particle size distributions of recycled glass cullet

\begin{tabular}{cc}
\hline Sieve size $(\mathbf{m m})$ & Recycled glass (\% passing) \\
\hline 5.0 & 99.8 \\
2.36 & 90 \\
1.18 & 57.9 \\
0.6 & 32.1 \\
0.3 & 10.6 \\
0.15 & 7.5 \\
0.075 & 4.7 \\
\hline
\end{tabular}

Table 3. Properties of intermixed-Type 1 and SP-Type 2 concrete surface layers after 28 days curing

\begin{tabular}{|c|l|l|c|c|c|c|}
\hline Type of samples & $\begin{array}{c}\text { Dry density } \\
\left(\mathrm{g} / \mathrm{cm}^{3}\right)\end{array}$ & $\mathrm{DS}$ & $\begin{array}{c}\text { Accessible } \\
\text { pores (\%) }\end{array}$ & $\mathrm{DS}$ & $\begin{array}{c}\text { Compressive } \\
\text { strength (MPa) }\end{array}$ & $\mathrm{DS}$ \\
\hline $\begin{array}{c}\text { Intermixed-Type 1 } \\
\text { (5\% } \mathrm{TiO}_{2} \text { by weight } \\
\text { of binder) }\end{array}$ & 2.05 & 0.11 & 18.30 & 5.5 & 28.2 & 7.2 \\
\hline $\begin{array}{c}\text { SP-Type 2 } \\
\text { (without } \mathrm{TiO}_{2} \\
\text { addition) }\end{array}$ & 2.11 & 0.05 & 14.62 & 3.5 & 35.7 & 6.2 \\
\hline
\end{tabular}


Table 4. Volume dust Particle distribution

\begin{tabular}{|c|c|c|c|c|c|c|c|c|c|c|c|}
\hline & \multicolumn{10}{|c|}{ Dust size $(\mu \mathrm{m})$} \\
\hline & 1 & 2 & 3 & 4 & 5 & 7 & 10 & 20 & 40 & 80 & 100 \\
\hline $\operatorname{Vol}(\%)$ & 3.5 & 9 & 9.5 & 7.5 & 6.5 & 10 & 8 & 20 & 17 & 9 & 0 \\
\hline
\end{tabular}

Table 5. Chemical compositions of dust

\begin{tabular}{|c|c|c|c|}
\hline Component & \% in weight & Component & \% in weight \\
\hline $\mathrm{SiO}_{2}$ & $68-76$ & $\mathrm{CaO}$ & $2-5$ \\
\hline $\mathrm{Al}_{2} \mathrm{O}_{3}$ & $10-15$ & $\mathrm{MgO}$ & $1-2$ \\
\hline $\mathrm{Fe}_{2} \mathrm{O}_{3}$ & $2-5$ & $\mathrm{TiO}_{2}$ & $0.5-1$ \\
\hline $\mathrm{Na}_{2} \mathrm{O}$ & $2-4$ & $\mathrm{~K}_{2} \mathrm{O}$ & $2-5$ \\
\hline
\end{tabular}




\section{LIST OF FIGURES}

Figure 1. Equipment used. Schematic diagram of $\mathrm{NO}_{\mathrm{x}}$ removal experimental set-up Figure 2. Equipment used. Dust chamber

Figure 3. a)Dust accumulation on the surface of samples in the chamber, b) (1) $10 \mathrm{~g}$ and (2) $37 \mathrm{~g}$ of dust were accumulated per $\mathrm{m}^{2}$ of surface

Figure 4. Photocatalytic $\mathrm{NO}_{\mathrm{x}}$ removal profiles of intermixed-Type 1 and SP-Type 2 samples

Figure 5. (a) and (b) SEM morphology of the intermixed-type 1 and SP-type 2 of concrete surface layers, respectively

Figure 6. The photocatalytic $\mathrm{NO}_{\mathrm{x}}$ removal of samples with dust accumulation on its surface.

Figure 7. Intermixed-Type 1 and SP-Type 2 samples cleaned by different processes

Figure 8. Photocatalytic $\mathrm{NO}_{\mathrm{x}}$ removal of samples after subjected to cleansing with a) water and $b$ ) water and brush process.

Figure 9. Influence of oil accumulation on photocatalytic $\mathrm{NO}_{\mathrm{x}}$ removal a) intermixedType 1 and b) SP-Type 2 samples

Figure 10. a) Photocatalytic $\mathrm{NO}_{\mathrm{x}}$ removal of the samples impregnated with motor oil; $\mathrm{b}$ ) the intermixed-Type 1 and SP-Type 2 samples cleaned by different cleansing methods.

Figure 11. a) SEM-EDX analysis of SP-Type 2 reference sample before mobile oil contamination, (b) SEM-EDX analysis of the SP-Type 2 reference sample after exposure to mobile oil contamination 


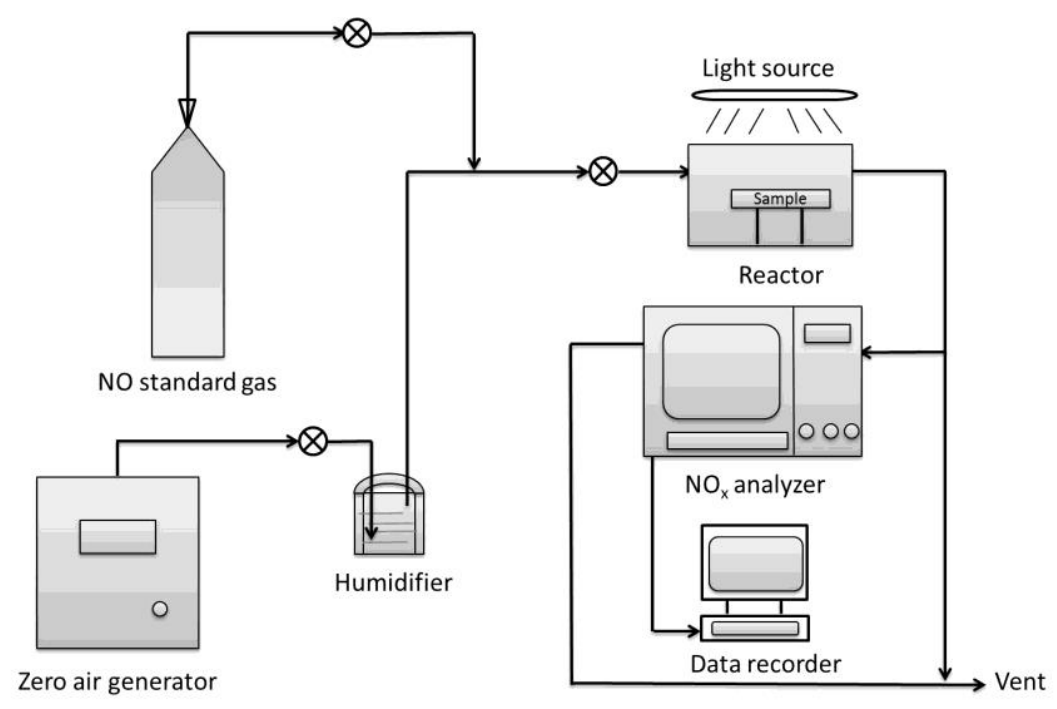

Figure 1. Equipment used. Schematic diagram of $\mathrm{NO}_{\mathrm{x}}$ removal experimental set-up

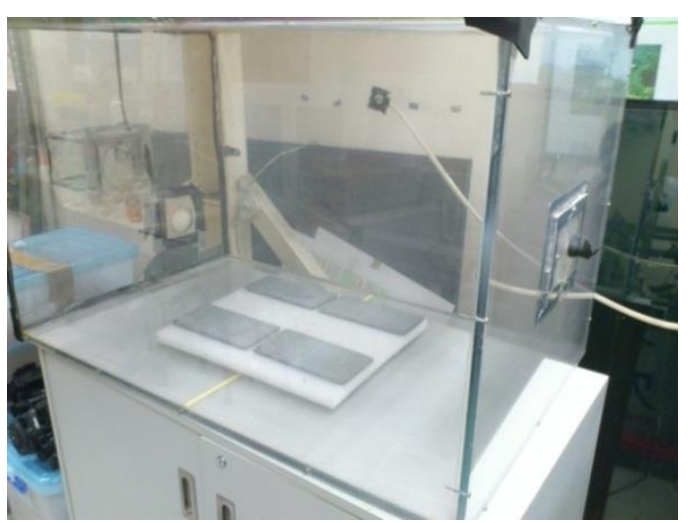

Figure 2. Equipment used. Dust chamber 


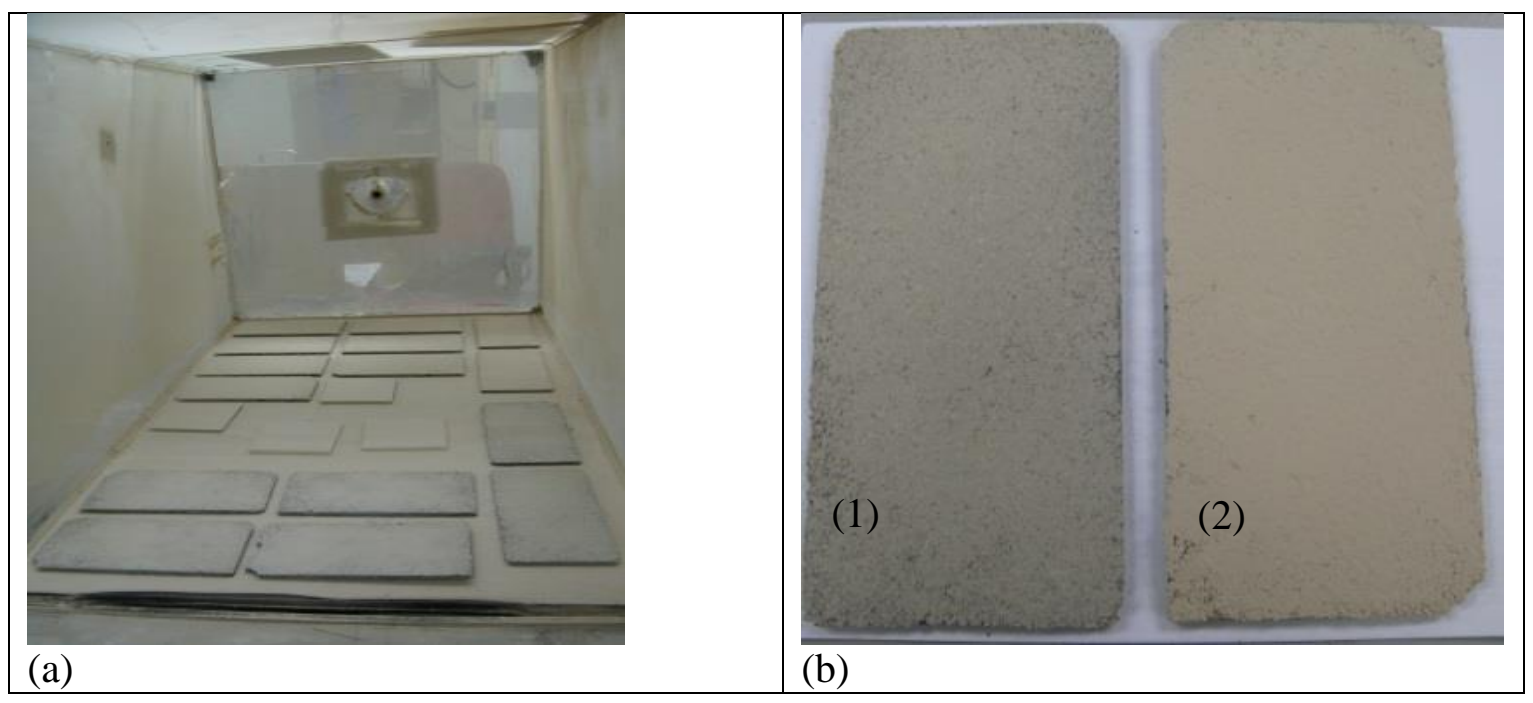

Figure 3. a)Dust accumulation on the surface of samples in the chamber, b) (1) $10 \mathrm{~g}$ and (2) $37 \mathrm{~g}$ of dust were accumulated per $\mathrm{m}^{2}$ of surface

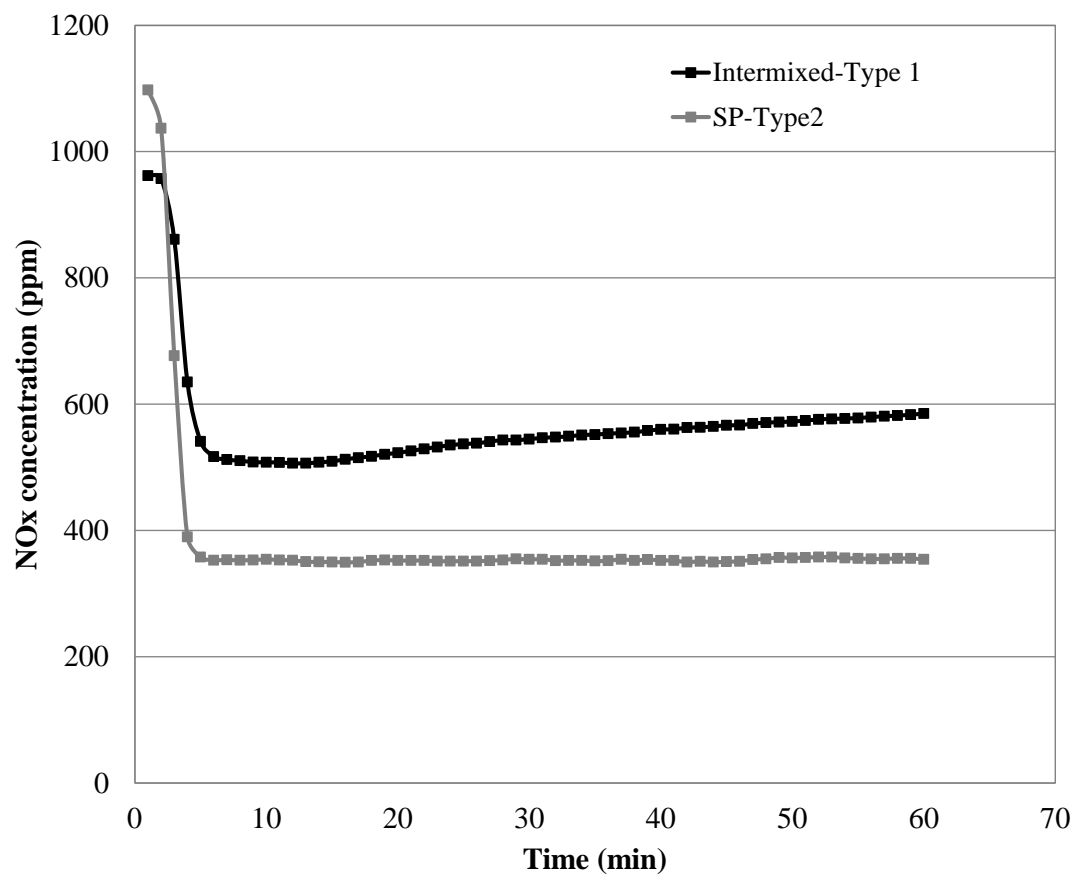

Figure 4. Photocatalytic $\mathrm{NO}_{\mathrm{x}}$ removal profiles of intermixed-Type 1 and SP-Type 2 samples 


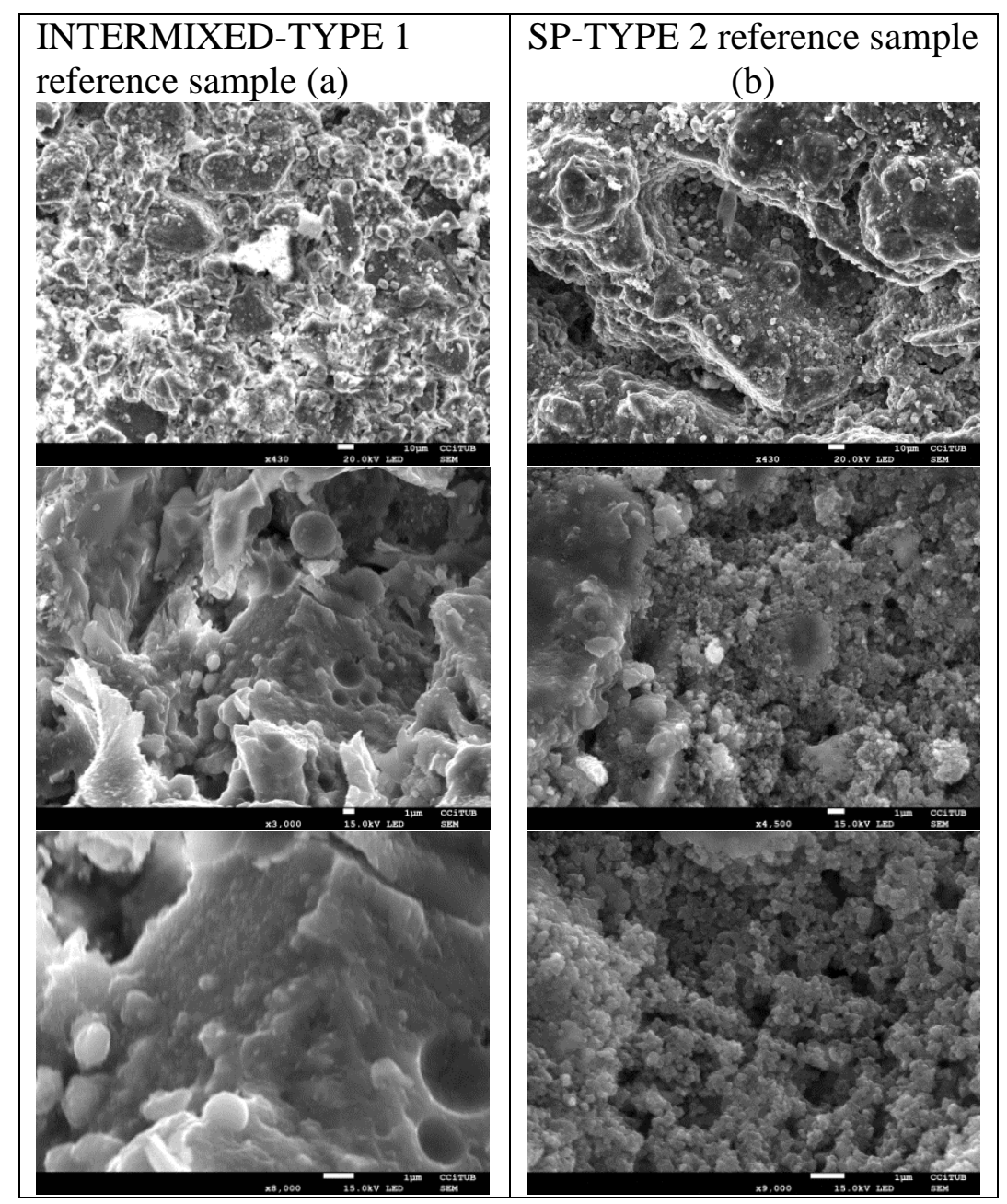

Figure 5. (a) and (b) SEM morphology of the intermixed-type 1 and SP-type 2 of concrete surface layers, respectively

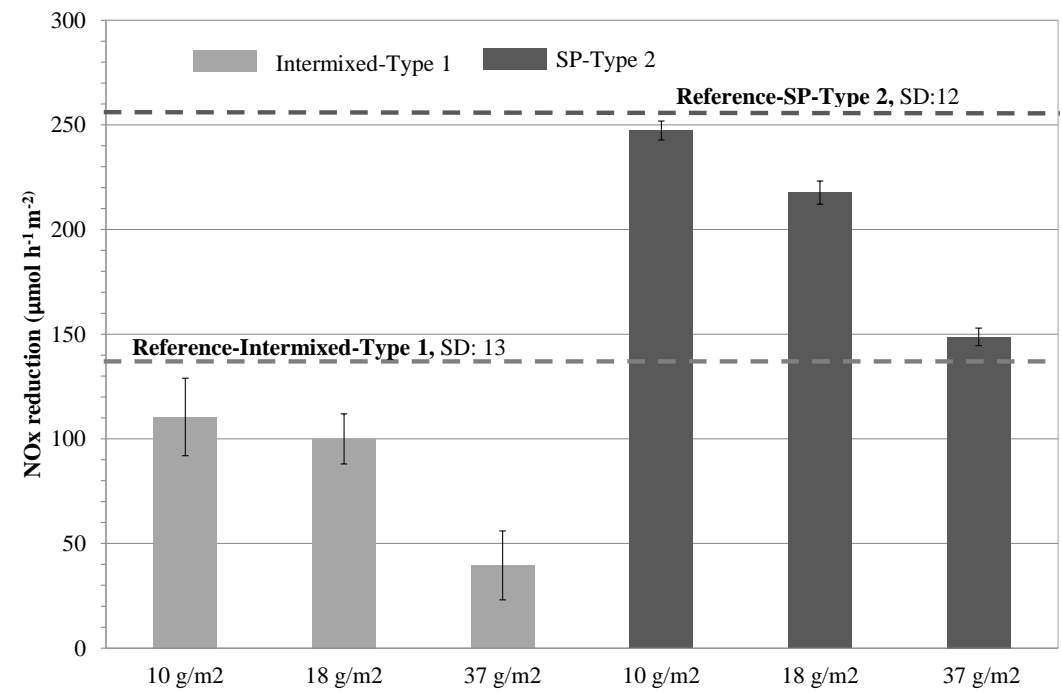

Figure 6. The photocatalytic $\mathrm{NO}_{\mathrm{x}}$ removal of samples with dust accumulation on its surface. 


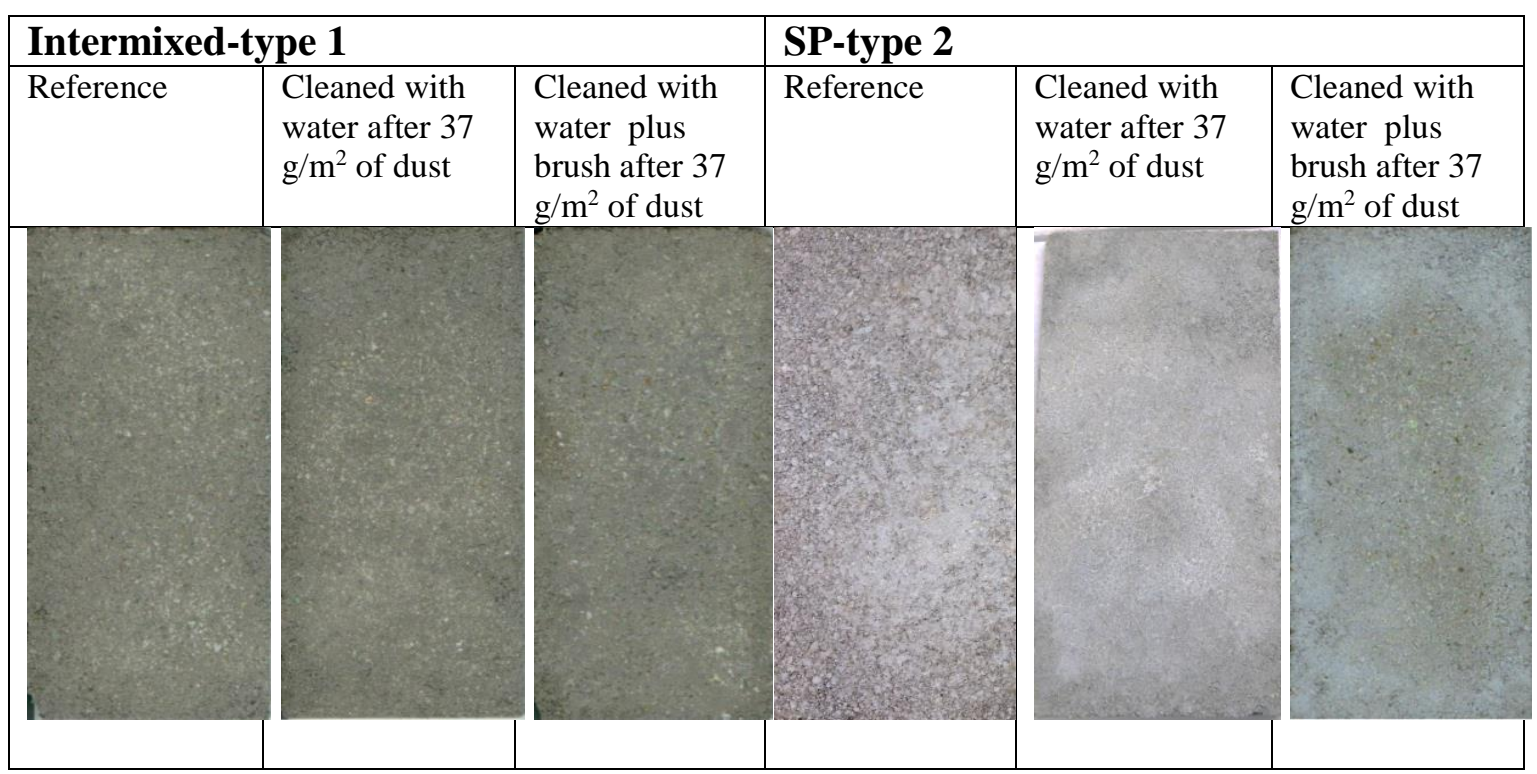

Figure 7. Intermixed-Type 1 and SP-Type 2 samples cleaned by different processes

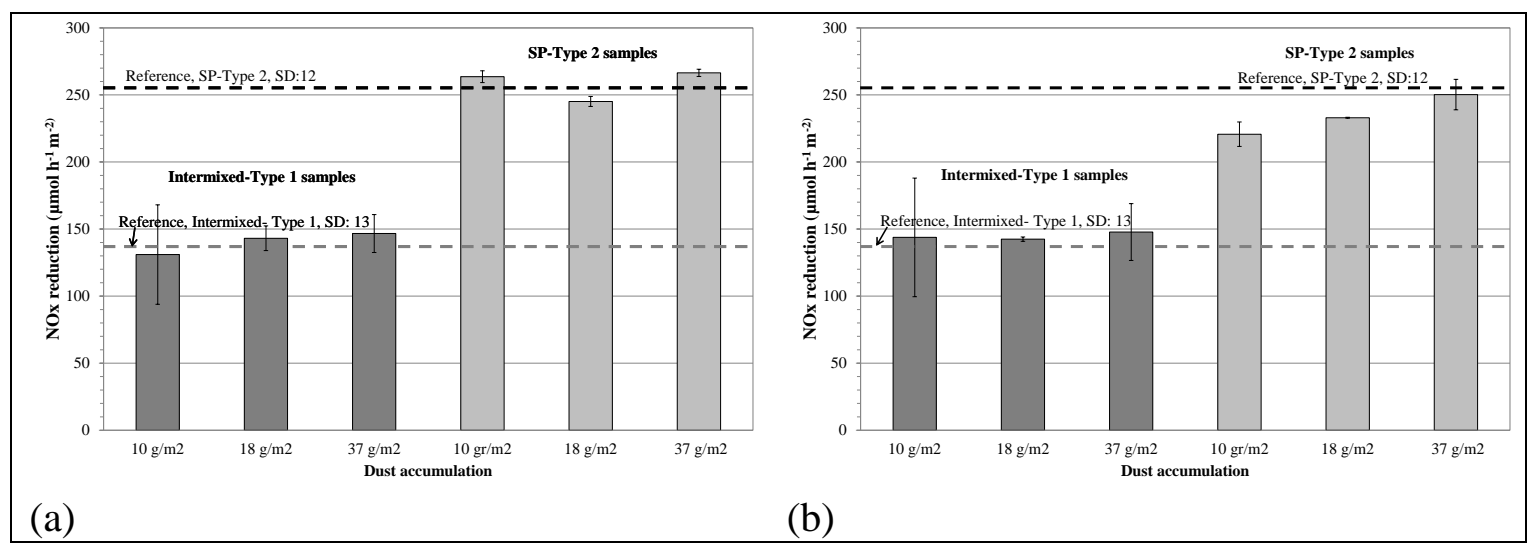

Figure 8. Photocatalytic $\mathrm{NO}_{\mathrm{x}}$ removal of samples after subjected to cleansing with a) water and $b$ ) water and brush process. 


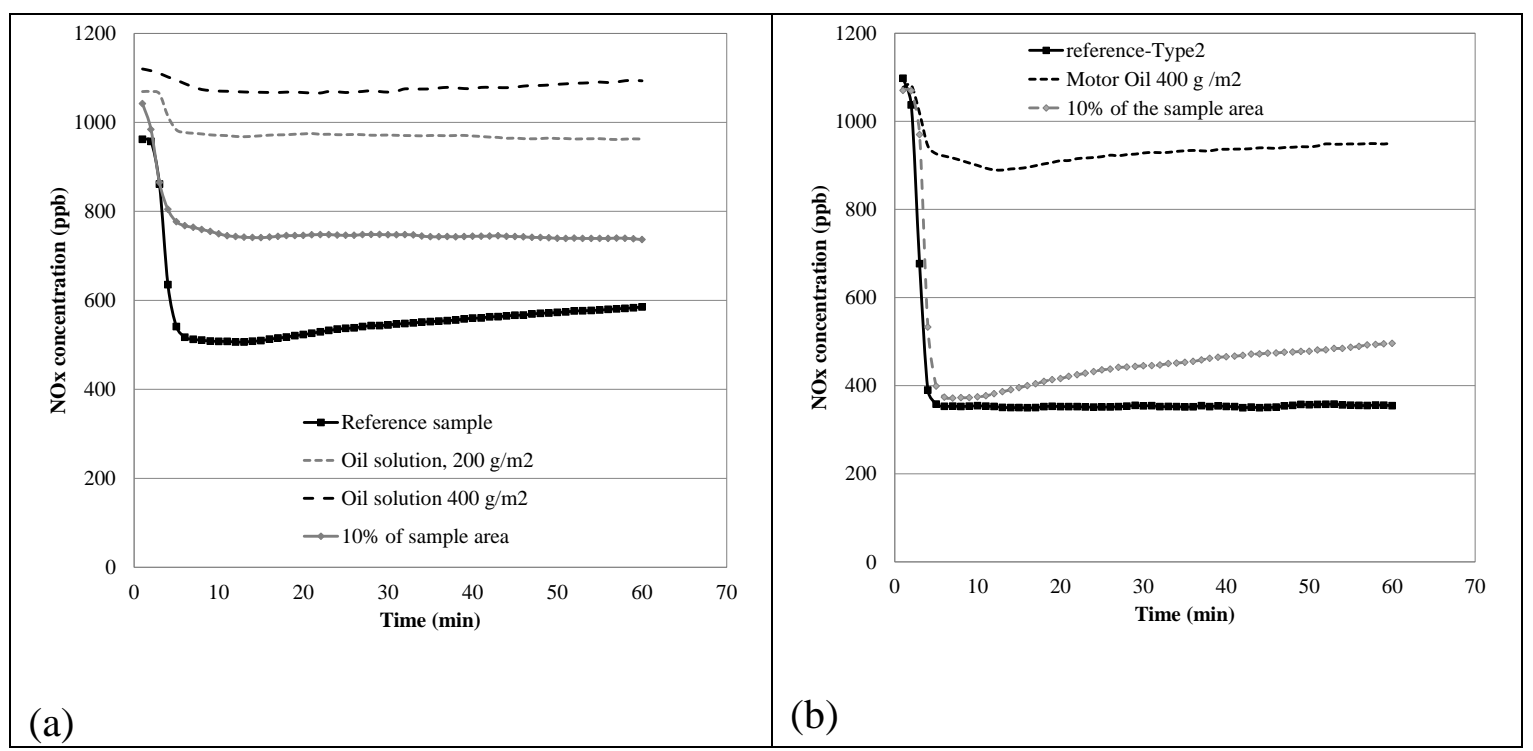

Figure 9. Influence of oil accumulation on photocatalytic $\mathrm{NO}_{\mathrm{x}}$ removal a) intermixedType 1 and b) SP-Type 2 samples

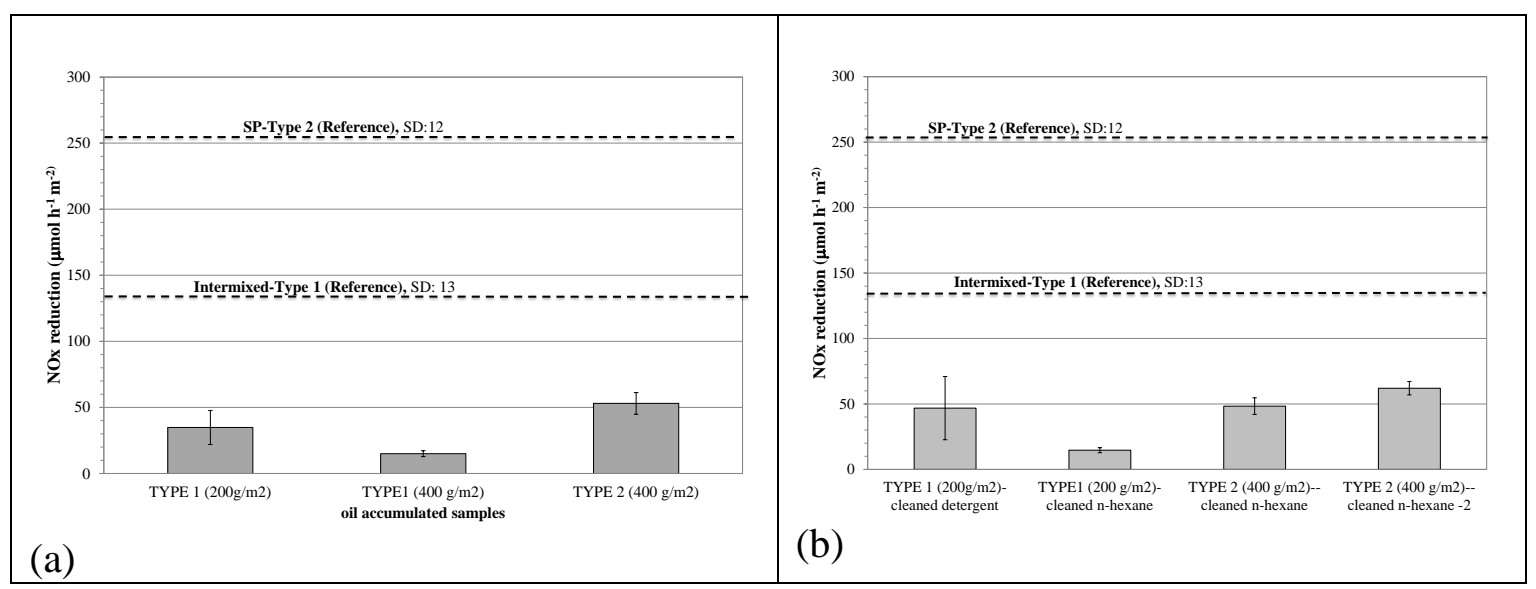

Figure 10. a) Photocatalytic $\mathrm{NO}_{\mathrm{x}}$ removal of the samples impregnated with motor oil; $\mathrm{b}$ ) the intermixed-Type 1 and SP-Type 2 samples cleaned by different cleansing methods. 


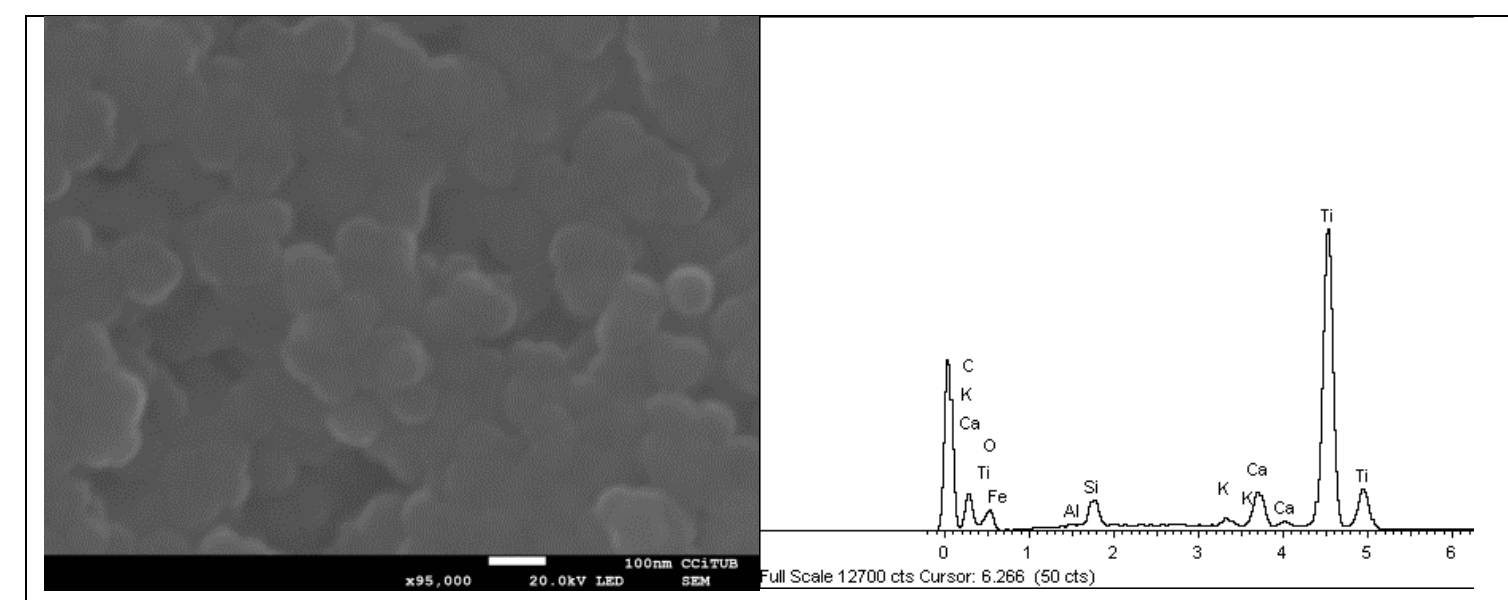

(a)
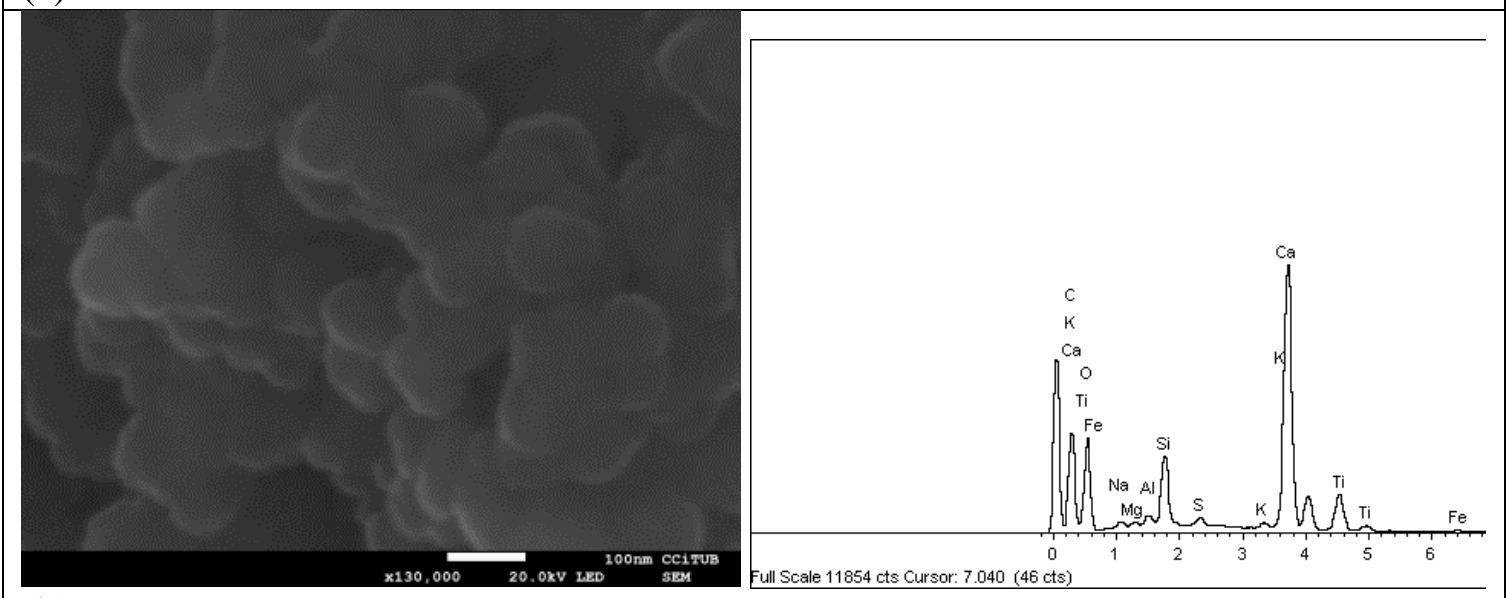

(b)

Figure 11. a) SEM-EDX analysis of SP-Type 2 reference sample before mobile oil contamination, (b) SEM-EDX analysis of the SP-Type 2 reference sample after exposure to mobile oil contamination 